GSI Journals Serie A: Advancements in Tourism, Recreation and Sports Sciences

(GSI Dergileri Seri A: Turizm, Rekreasyon ve Spor Bilimlerindeki Gelişmeler)

ATRSS 2021, 4 (2): 99-114 - Araştırma Makalesi - Received/Geliş T.: 17.03.2021 - Published/Kabul T.: 25.04.2021

\title{
Sürdürülebilir Turizm Hareketi Olarak Slow Food: Germiyan Örneği
}

Burcu DEMIR, Ege Üniversitesi, Sosyal Bilimler Enstitüsü, Turizm Rehberliği Anabilim Dalı, demirburcu512@gmail.com, İzmir, Türkiye, ORCID: 0000-0003-2556-9757

\begin{abstract}
Öz
İtalya'da 1986 yılında başlayan Slow Food Hareketi, 1989 yılında uluslararası boyuta ulaşmıştır. Dünyada 160 üye ülkesi bulunan bu hareket daha kaliteli bir yaşamı amaçlamaktadır. "Sürdürülebilirlik" kavramı 1980'lerde gündeme gelmiştir ve Slow Food Hareketi ile benzer amaç ve ilkelere sahiptir. Çalışmada Slow Food Hareketi ve sürdürülebilir turizm bir arada ele alınmıştır. Geleceği korumaya yönelik bu iki alanın birlikte sağladığı yararları araştırmak, Slow Food Hareketi'nin turizm ve günlük yaşam açısından Germiyan'da yarattı̆̆g etkiyi incelemek amaçlanmıştır. Araştırma alan olarak Türkiye'nin ilk ve tek Slow Food Köyü Germiyan seçilmiştir, araştırma yöntemi olarak yarı yapılandırılmış görüşme ve yapılandırılmamış gözlem teknikleri kullanılmıştır. Çalışma grubu için seçilen kişiler amaçlı örneklem yöntemlerinden ölçüt örnekleme yöntemiyle belirlenmiştir. Germiyan'ın yerel halkından sekiz kişi ve Slow Food Hareketi'ne öncülük eden Çeşme Rotary Kulübü eski üyelerinden iki kişi ile görüşme gerçekleştirilmiştir. Görüşmeler iki haftalık zaman diliminde yürütülmüştür. Yapılandırılmamış gözlem tekniği Beşinci Germiyan Festivali ve görüşmeler esnasında kullanılmıştır. Yapılan gözlemlerin ana amacı festival süresince ve festival dışında köy sakinlerinin ziyaretçilere karşı sözlü ve sözlü olmayan tutumlarının, satış yapan ve işletme sahibi olan bireylerin davranışlarının incelenmesi ve karşllklı iletişimlerinin gözlemlenmesidir. Elde edilen bulgular doğrultusunda Slow Food Hareketi'nin turizmde ve günlük yaşamda olumlu yönde değişiklikler gerçekleştirdiği, yerel halkın kendi içindeki iletişimini kuvvetlendirdiği, ekonomik katkı sağladığı sonucuna varılmıştır. Bunun yanı sıra ekonomik yönün ă̆ır basmasıyla birlikte ürünlerin fiyatlarının yükseltilmesi, doğal olmayan ürünlerin satılması, kültürel dokunun bozulması gibi hareketin amaçlarına ters düşen etmenler olumsuz sonuçlar arasında yer almıştır.
\end{abstract}

Anahtar Kelimeler: Slow Food, Yavaşlık, Sürdürülebilirlik, Sürdürülebilir Turizm, Germiyan.

\begin{abstract}
Beginning in Italy in 1986 Slow Food movement reached an international dimension in 1989. The movement which has thousands of members in 160 countries aims for a higher quality of life for the world. The term "sustainability" came up in the 1980s and has similar purposes and principles with the Slow Food movement. In the study, Slow Food and sustainable tourism have been discussed together. Researching the mutual benefits of these fields on protecting the future and investigating the impact of the Slow Food movement on tourism and the daily life of the people who are living in Germiyan village is the aim of this research. The Germiyan village, which is the first and only Slow Food village of Turkey is chosen as the research area and semi-structured interview and unstructured observation techniques are used as the research methods. The attendants for the study group are chosen by criterion sampling method which is a type of purposeful sampling method. The data is collected from eight people who are locals of Germiyan village and also two people who are former members of the Çeşme Rotary Club. The interviews have been conducted for two weeks. The unstructured observation technique has been applied in the 5th Germiyan Festival and interviews. The main purpose of the observations is to determine the verbal and non-verbal attitudes of the local people towards the visitors during and out of the festival. Another purpose is to investigate the behaviors of the salespeople and the business owners and observation of their mutual relationships with visitors. Based on the results of the study, which has researched the effect of Slow Food on tourism and daily life, it is concluded that Slow Food has a positive impact on the daily life of the local people and the tourism activity of the village. It also made the communication of the local people with each other stronger and also contributed to the economy of locals. Besides the study showed that the occurrence of some negative elements which contradict the aim of the movement such as inflation of the prices, trade of unnatural products, and defecting of the cultural texture.
\end{abstract}

Slow Food As A Sustainable Tourism Movement: The Case of Germiyan

Keywords: Slow Food, Slowness, Sustainability, Sustainable Tourism, Germiyan. 


\section{Giriş}

“...Hayat içinde sürekli yiyerek yavaş, temkinli ama kararlılıkla ilerleyen salyangoz, cüssesinden beklenmeyecek mesafeler aşar ve geçtiği yerlerde izini bırakır"'(Petrini, 2012). Carlo Petrini öncüsü olduğu Slow Food Hareketi'ni ve hareketin simgesini bu sözleriyle açıklamaktadır. Yavaş hareketinin başlangıç noktasını Slow Food (yavaş yemek) oluştururken devamında yavaş şehirler, yavaş medya, yavaş para, yavaş turizm gibi kavramlar ortaya çıkmaya başlamıştır. Bunun sebebi olarak insanların giderek daha hızlı yaşamaya ve tüketmeye başlaması gösterilebilir. Olumsuz yönde dünyayı etkilemeye başlayan bu hızlı yaşam ve aşırı tüketim yaklaşık 10 bin yıl önce ortaya çıkan ve Jared Diamond'a göre tarihin en büyük aldatmacası (Diamond, 2013) olan "Tarım Devrimi” ile başlamıştır. Çünkü insan bu geçiş sürecinde sahip olduğu birçok yeteneğini kaybetmiştir ve toprağa bağımlı hale gelmiştir. Bu bağlılık hızlanmayı da beraberinde getirmiştir. Ürünün zamanında ekilmesi, biçilmesi ve muhafaza altına alınması yılları, mevsimleri, günleri ve saatleri kısıtlayıp insanı hızlı hareket etmeye zorlamıştır. Standage’e göre; “Tarıma geçişin, sanatsal işlerle uğraşmak, yeni zanaat ve teknolojiler geliştirmek gibi işlerde insanlara daha fazla zaman bıraktı̆̆ı düşünülmüştür. Bu açıdan tarım, avc1-toplayıcıların kıt kanaat geçindikleri yaşam tarzlarından kurtulmaları şeklinde gösterilir. Ne var ki tersi durum da bir o kadar doğrudur" (Standage, 2017).

Hızlanmayı etkileyen devrimlerden bir diğeri 18. yüzyılda gerçekleşen Sanayi Devrimi'dir. Sanayi Devrimi'nin sonuçları gelişmiş ülkelerdeki insanların yaşam beklentilerini artırırken gerçekte toplumun dengesini bozmuş, fiziksel ve psikolojik yıkımlara yol açmış ve doğal yaşamda daha fazla hasara neden olmuştur (Kazcynski, 1996). Ağır çalışma şartları ve uzun çalışma saatleriyle birlikte kötü beslenme ve çeşitli hastalıklar ortaya çıkmıştır. İlerleyen dönemlerde ise hızlı yaşama ve tüketime etki eden teknolojiler gelişmeye başlamıştır. Bugün görülen teknolojik devrimlerin gelişimi ve mevcut hali yalnızca elli yıllık bir süreci kapsamaktadır (Amin, 2017). Bu süreç tüketim toplumunun oluşmasını hızlandırmıştır. Bu tüketim kültüründe insanların tamamı daima yeni ürünlerin ve yeni heyecanların peşinde olmaya sürüklenmektedir (Stavrides, 2016). Bu da klasik tabirle kapitalist sistemin bir sonucudur. Kent yaşamına ait ve buradan kırsala yayılan bir sistem olan kapitalizm (Goody, 2012), dünyanın her yerinde etkisini göstermektedir. Endüstriyel kapitalizm hızla beslenirken ürünlerini daha hızlı üretip dağıtan şirketler rakiplerinden üstün olmaktadır ve anaparayı kâra çevirerek bunu da yatırıma dönüştürebilmektedir (Honore, 2008). Hayatı kolaylaştırdığı ve hızlandırdığı düşünülen birçok yeniliğin bu açılardan ele alındığında dünyayı olumsuz yönde etkilediği görülebilmektedir. "Yavaş" kavramının hatırlanması bu yüzden önemlidir.

Yavaş felsefesinde hızlının karşıtı olmaktan öte bu felsefeyi bir yaşam biçimine dönüştürerek hayatın her alanına taşıma düşüncesi vardır. Yavaşlık felsefesi sadece şu an yaşayan insanların değil, gelecek nesillerin hayatının da belirlenmesinde büyük rol oynamaktadır. Hareketin manifestosunda yer alan "Dinamik yaşama karşı rahat yaşamı savunuyoruz. Üretkenliği aşırılıkla karıştıran çok sayıdaki insana, yavaşça, keyif alma süresini uzatacak şekilde uygulanması gereken, uygun dozda bir duyumsal haz öneriyoruz" (Sepúlveda ve Petrini, 2018) sözleri hareketin amacını aktarmaktadır.

Yemek kültürünü ve insan sağlığını etkileyen hızlı yemek (fast food) ürünlerine karşılık, Slow Food Hareketi "yavaş yemek" kavramını ve beraberinde getirdiği yaşam felsefesini sunmaktadır. Bunu farklı projelerle ve oluşumlarla insanlara ulaştırmaktadır. Öte yandan yerel ürünü ve yerel ekonomiyi destekleyen Slow Food Hareketi ile benzer paydaşlara sahip olan sürdürülebilir turizmin bir arada olması, uygulamaya geçilen bölgede gelişmeler sağlayabilecek potansiyele sahiptir. Sürdürülebilir turizm doğal, kültürel, sosyal ve estetik değerlerin korunup geliştirilmesi ve devamlılı̆̆ının sağlanması (Kuter ve Ünal, 2009) olarak tanımlanır ki bu da Slow Food Hareketi'nin felsefesinde ve ilkelerinde yer almaktadır. Bunlara ek olarak sürdürülebilir turizmin aşırı tüketimi ve atığı azaltma, çeşitliliği koruma, yerel ekonomiyi destekleme, yerel toplulukları turizm sektörüne dâhil etme, yerel ekonomiyi destekleme, yerel denetimi ve kaynak verimliliğini sağlama gibi ilkeleri de Slow Food Hareketi'nin ilkeleri ile örtüşmektedir (Garrod ve Fyall, 1998; Stabler ve Goodall, 1997; UNEP, 2009). 
Bu çalışmada, Türkiye'nin ilk ve tek Slow Food köyü olan ve turizm hareketliliğinin içerisinde yer alan Germiyan'ın Slow Food Hareketi ile tanışmasıyla birlikte günlük yaşamdaki sosyal, kültürel ve ekonomik değişimleri incelenmiştir. Bununla birlikte Slow Food Hareketi ve turizm arasındaki ilişki araştırılmıştır. Türkiye'de yavaş hareketi ile ilgili çalışmalar yoğun şekilde devam ederken turizm ve Slow Food Hareketi'nin birlikte ele alındığı çalışmalara katkıda bulunmak hedeflenmiştir.

\section{Kavramsal Çerçeve}

\subsection{Slow Food Hareketi}

İtalya'nın Bra şehrinde 1949 yılında dünyaya gelen Carlo Petrini uzun yıllar geleneksel yemeklerin ve kültürün korunması için uğraş, verdikten sonra ilk ses getiren eylemini 1986 yılında Roma Piazza di Spagna'daki McDonalds restoranın açlışında gerçekleştirmiştir. Carlo Petrini'nin bu eylemiyle birlikte Slow Food (Yavaş Yemek) Hareketi de ortaya çıkmıştır. Slow Food Hareketi 1989 yılında uluslararası bir boyuta ulaşmıştır ve bu tarihte 80.000'i aşkın üyeye sahiptir (Güven, 2011). Aynı yıl Paris'te toplanan on beş ülke delegesiyle Slow Food manifestosu imzalanmıştır (Slow Food International, 2019). Bu ülkeler; Arjantin, Avusturya, Brezilya, Danimarka, Fransa, Almanya, Hollanda, Macaristan, İtalya, Japonya, İspanya, İsveç, İsviçre, Amerika Birleşik Devletleri ve Venezuela'dır. Günümüzde 160 ülkede 1500'den fazla convivium'a (yerel şube) sahip olan Slow Food organizasyonu her geçen gün milyonlarca üyesine yenisini eklemektedir. Dünya çapında ürün biyoçeşitliliğini korumak için çeşitli organizasyonlarla, etkinliklerle, kampanyalarla üreticiler ve tüketiciler arasında bağlantı sağlamaktadır.

Slow Food'un felsefesinde birbirine bağlı üç temel kavram yer almaktadır. Bu kavramlar, iyi (good), temiz (clean) ve adil (fair) kavramlarıdır (Slow Food International, 2019). İyi ilkesi kaliteyi, lezzeti ve sağlığı; temiz ilkesi çevreye zarar vermeden üretimi; adil ilkesi ise tüketici ve üretici açısından makul fiyatları içinde barındırır. Slow Food'a bağlı Ark of Taste (Nuh'un Ambarı) projesi ile de tehdit altında olan hayvan türleri, yiyecek çeşitleri ve tahıllar koruma altına alınmaktadır. Lezzet eğitimi kapsamında Ark of Taste tarafından seçilen ürünler için geçerli kriterler şu şekildedir (Yurtseven vd., 2010): (1) Ürünler benzersiz kalitede olmalı; (2) Bir bölgeye özgü ya da o bölgeye uyum sağlamış, yerel hammaddelerden üretilmiş, geleneksel uygulamalarla yapılmış olmalı; (3) Ürünün yerel alanla geleneksel, tarihi, sosyo-ekonomik bağ1 olmalı ve o yerin ismiyle bağdaşmalı; (4) Küçük ölçekte üretilmeli ve üretim sınırlı olmalı; (5) Yok olma tehlikesi altında olmalı. Slow Food'un işlevleri "koruma" ve "eğitim" olarak iki temel başlık altında toplanabilmektedir. Koruma işlevi, yok olma tehlikesi altındaki bitki ve hayvan türlerini, tarımsal yöntem ve teknikleri koruyup kayıt altına alır. Eğitim işlevi ise insanların tatma yeteneklerini geliştirmeye ve yemek konusundaki bilgilerini artırmaya yöneliktir (Nosi ve Zanni, 2004).

Slow Food'un Türkiye' de faaliyet gösterdiği en erken tarih 2006 yılıdır. Bu tarihte Carlo Petrini, University of Gastronomic Science'da öğrenim gören üç Türk öğrenci ile Türkiye'yi ziyaret etmiştir ve Slow Food kapsamında İstanbul, Gökçeada, Ayvalık, Tire, İzmir, Çeşme ve Bodrum gibi merkezleri gezmiştir. Bu ziyaretlerin ardından Türkiye' de ilk conviviumların kurulması için çalışmalara başlanmıştır (Gezeroğlu, 2013). Bugün Türkiye'de toplam yirmi dört convivium bulunmaktadır. Bunun yanı sıra Türkiye'nin farklı bölgelerinden elli dokuz ürün Ark of Taste Projesi kapsamındadır. Türkiye'de conviviumlar ve Ark of Taste ürünlerinin dışında üç tane de Yeryüzü Pazarı bulunmaktadır. Bu Yeryüzü Pazarları Şile, Gökçeada ve Foça' da yer almaktadır (Slow Food International, 2019).

\subsection{Germiyan}

Germiyan köyünün kuruluş tarihi net olmamakla birlikte Germiyanoğluları Beyliğine dayandırılmaktadır. Germiyanoğlu'larının 13. yüzyılda Batı Anadolu' ya geldiği düşünülmektedir (Varlık, 1996). Yerel halkın anlatımına göre köy, 500 yıl önce Germiyanoğlularının bir toprağı olan Kütahya'dan buraya göçen Kocakeçi lakaplı bir Yörük tarafından kurulmuştur (Kurt, 2016). Soyağaçlarına bakıldığında ise köyün geçmişi en az 250 yıl öncesine dayanmaktadır ve köy nüfusunun tamamına yakını Kocakeçi lakaplı Mehmet'in beş oğlunun soyundan gelmektedir (Önen, 1987). 20. yüzyılın baslarına bakıldığında 
ise Rumlarla etkileşim içinde oldukları ancak Çeşme Yarımadası'nda bulunan diğer yerleşim alanlarından farklı olarak az sayıdaki Türk köylerinden biri olduğu görülmektedir (Önen, 2017). Rumlarla etkileşim halinde olan bu Türkmen köyünde yöreye özgü birtakım tatlar vardır. Bunlara örnek olarak; Germiyan ekmeği, kopanisti, glika, bazina, damat kurabiyesi, kına lokumu, sütlü bulgur, kaburga dolması, çalkama ve çullama sıralanabilir.

Germiyan Türkiye'nin ilk “Slow Food Köyü” olarak ismini duyurmuştur. İzmir' in Bardacık Birliği'ne dâhil olan köyde Slow Food sürecinden önce Çeşme Rotary Kulübü tarafından kurulmuş bir birlik mevcuttur. Çeşme Rotary Kulübü, birliğin amaçlarına uygun bir hareket olan Slow Food'u Germiyan köyü ile tanıştırıp köy değerlerinin uluslararası boyut kazanmasını hedeflemiştir. Bu doğrultuda köyden yirmi yedi, Çeşme Rotary Kulübü'nden beş olmak üzere toplam otuz iki katılımcı ile Germiyan'ın Slow Food köyü ilan edilmesi için bir yıl sürecek hazırlık sürecini başlatacak olan protokol 16 Mayıs 2016'da imzalanmıştır ve 2017 yılında Germiyan resmi olarak Slow Food köyü olmuştur (Kurt, 2016; Gezgin, 2019). Bu sayede kültürel, doğal ve tarihsel değerlerini korumanın yanı sıra yerel ürünlerini de koruma altına alabilecek bir köy haline gelmiştir (Yeşiltuna, 2016). Hareketin sloganı olarak “Eğer insanlar sağlıklı olmak istiyorsa, yedikleri yiyecekler de sağlıklı olmak zorundadır" kullanılmıştır (Özkan vd., 2016).

Çeşme Belediyesi tarafından oluşturulan “9 Durak 9 Deneyim” adıyla başlatılan bir proje kapsamında Çeşme çevresinde dokuz noktada yılın farklı zamanlarında festivaller düzenlenmektedir (Çeşme Belediyesi, 2019). Bu noktalardan birisi de Germiyan köyüdür. Yerel yönetim ve derneklerin katkılarıla ilk defa 2014 yılında düzenlenen festivale yoğun katılım sağlanmıştır ve bu durum festivalin tekrarlanmasına öncülük etmiştir (Kurt, 2016).

\subsection{Sürdürülebilir Turizm}

Sürdürülebilirlik kavramı ekonomi, kalkınma, kentleşme, toplum, tarım gibi birçok alanda kullanılmaktadır. Bu alanlardan biri de hizmet sektöründe yer alan turizm disiplinidir. Sürdürülebilir turizmi incelemek için öncelikle sürdürülebilirlik kavramına değinilmelidir. Sürdürülebilirlik kavramının ortaya çıkışı İkinci Dünya Savaşı'na dayanmaktadır. Her savaş dünyaya, yeryüzü ve gökyüzü fark etmeksizin büyük çaplı zararlar vermiştir. Ancak İkinci Dünya Savaşı dünyadaki ekolojik dengeyi bozacak, sanayileşmeyi artıracak ve bunun sonucunda da kaynakların tüketimini hızlandıracak kadar etkili olmuştur. Çevre sorunları bir ülke ya da bir bölgeyi etkilemenin ötesinde yeryüzünün tamamında hâkim olmaya başlamıştır (Sipahi, 2010). Bir yüzyıl öncesinde ise, Sanayi Devrimi ile birlikte tüm alanlarda yaşanan gelişmeler nedeniyle hızlı sanayileşme çabalarının bir sonucu olarak doğal kaynaklar ve çevrede telafi edilemez derece zararlar meydana gelmiştir (Kınacı, Pehlivan ve Seyhan, 2011).

Ağır sanayileşmenin getirmiş olduğu sorunları çözmek adına da ilk adım 1972 yılında atılmıştır. Stockholm'de düzenlenen Birleşmiş Milletler Çevre Konferansı'nda çevrenin korunması ve geliştirilmesi adına kararların yer aldığı bir bildiri hazırlanmıştır (Pallemaerts, 1997). Birleşmiş Milletler 1982 yılında ikinci adımını atarak “Dünya Doğa Şartı (World Charter for Nature)”nı kabul etmiştir. Hukuki bakımdan bağlayıcılığı olmamakla birlikte çevre hukukunun ana ilkelerinden birini oluşturan sürdürülebilir kalkınma kavramına ilk defa yer vermesi açısından önemlidir (Güneş, 2012). 1987 yılında “Ortak Geleceğimiz", diğer adıyla "Brundtland Raporu" Dünya Çevre ve Kalkınma Komisyonu tarafından yayınlanmıştır. Raporda gelecek tehditleri, sürdürülebilir kalkınma, sürdürülebilir dünya ve ekonomi, çevre ve kalkınma arasındaki bağlar, yiyecek güvenliği, ekosistem, enerji kaynakları, endüstriyel gelişim ve etkileri gibi konulara yer verilmiştir. Bu raporda sürdürülebilir kalkınma günümüzün gereksinim ve beklentilerini, gelecek nesillerin kendi gereksinim ve beklentilerini karşılama imkânlarını tehlikeye atmadan gidermek olarak tanımlanmıştır (United Nations, 1987). Rapor, bu konuda açık bir tanıma yer veren ilk çalışmadır. Brundtland Raporu; Birleşmiş Milletler Çevre ve Kalkınma Konferansı'nın ardından Avrupa Birliği Beşinci Çevre Eylem Programı (1995), Birleşmiş Milletler İnsan Habitatı Konferansı (İstanbul-1996), Rio+5 Forumu (Rio de Janerio-2002) ve Dünya Sürdürülebilir Gelişme Konferansı (Johannesburg-2002) gibi uluslararası girişimlere öncülük etmiştir (Ediger ve Çiftçi, 2019). 
Sürdürülebilir turizm, sürdürülebilir kalkınmanın bir parçasıdır ve onun ilke ve stratejilerinin turizme uyarlanmasıyla ortaya çıkmıştır (Kınacı ve diğ., 2011).Turizmde sürdürülebilirlik kavramı; “...turizmin kaynağı olan doğal, tarihi, kültürel, sosyal ve estetik değerlerin korunup geliştirilerek çekiciliklerinin devamının sağlanmasını ifade etmektedir"(Kuter ve Ünal, 2009). Swarbrooke (1999) sürdürülebilir turizmin önemini vurgularken bu kavramın; yavaş ve kontrollü kalkınma sağladığını, nitelikli ve uzun vadeli olduğunu da belirtmiştir.

Sürdürülebilir turizmin daha etkili kullanılması ve anlaşılabilmesi için birtakım ilkeler vardır. Bu on temel ilkeyi şu şekilde sıralamak mümkündür (Garrod ve Fyall, 1998; Stabler ve Goodall, 1997; UNEP, 2009):

- Kaynakların Kullanımında Sürdürülebilirlik: Doğal, sosyal ve kültürel kaynakların kullanımını korumak ve sürdürmek önemlidir, bu durum uzun süreli iş becerisi sağlar.

- Aşırı Tüketimi ve Atığı Azaltmak: Aşırı tüketim ve atıkların azaltılması uzun vadeli çevresel zararların telafi edilmesinin maliyetini önler ve turizm kalitesine katkıda bulunur.

- Çeşitliliği Korumak: Doğal, sosyal ve kültürel çeşitliliği korumak ve desteklemek uzun vadeli sürdürülebilir turizm için önemlidir ve endüstri için esnek bir temel oluşturur.

- Turizmi Planlamaya Entegre Etmek: Ulusal ve yerel bir stratejik planlama yapısına entegre edilen ve çevresel etkinin değerlendirmelerini üstlenen turizm, uzun vadeli uygulanabilirliği artırır.

- Yerel Ekonomileri Desteklemek: Çok çeşitli yerel ekonomik faaliyetleri destekleyen ve çevresel maliyetleri ve değerleri dikkate alan turizm hem ekonomileri korur hem de çevresel zararların önüne geçer.

- Yerel Toplulukların Dâhil Edilmesi: Yerel toplulukların turizm sektörüne tamamen dâhil edilmesi, sadece kendilerine ve genel olarak çevreye yarar sağlamaz aynı zamanda turizm deneyiminin kalitesini artırır.

- Paydaşlara ve Halka Danışılması: Birbirleriyle yan yana çalışabilmeleri ve potansiyel çıar çatışmalarının çözülebilmesi için turizm endüstrisi ile yerel topluluklar, kurum ve kuruluşlar arasındaki danışma esastır.

- Personelin Eğitilmesi: Her seviyede yerel personelin işe alınmasıyla birlikte, sürdürülebilir turizmi iş uygulamalarına entegre eden personel eğitimi turizm ürününün kalitesini de artırır.

- Sorumlu (Güvenilir) Bir Turizm Pazarlaması: Turizme tam ve güvenilir bilgiler sağlayan pazarlama, turistik alanların doğal, sosyal ve kültürel çevrelerine saygıyı artırır ve müşteri memnuniyetini yükseltir.

- Araştırma Yapmak: Devamlı araştırma yapmak ve endüstriyi etkili verilerle ve analizlerle takip etmek destinasyonlara, endüstriye ve tüketiciye çözüm sağlama açısından önemlidir.

Bu maddelere ek olarak sürdürülebilir turizmin amaç ve faydalarında yer alan kültür, biyoçeşitlilik, çevre, kaynak ve ekonomi gibi alanları kapsayan maddeler mevcuttur. Slow Food Hareketi'nin manifestosu ve üç temel ilkesi sürdürülebilir turizmin ilke, amaç ve faydalarını da kapsamaktadır. Bu nedenle Slow Food Hareketi ve sürdürülebilir turizmin ortak amaçlar taşıdığı açıkça ifade edilebilir.

Literatürde Slow Food Hareketi'nin sürdürülebilir turizm ile bir arada çalışıldığı kaynaklar kısıtlıdır. Jung, Ineson ve Miller'ın (2014) “The Slow Food Movement and Sustainable Tourism Development: A Case Study of Mold, Wales" başlıklı çalışması yarı yapılandırılmış görüşme tekniği kullanılarak hazırlanmıştır ve Slow Food Hareketi'nin sürdürülebilir turizme etkisi araştırılmıştır. Çavuş, Kaya ve Demirtaş'ın (2019) "Sürdürülebilir Turizm Açısından Slow Food Hareketine Bakış ve Türkiye Uygulamaları" başlığı altında yaptıkları çalışma konuyu doğrudan ele almaktadır. Bucak ve Turan'ın (2016) “Bölge Turizmine Yeni Akımların Etkisi: Gökçeada Yavaş Yemek Örneği” isimli makalesi, Gökçeada özelinde Slow Food Hareketi'nin turizme etkisini nitel araştırma yöntemiyle inceleyen bir çalışmadır. Özgürel ve Avcıkurt'un (2018) “Yavaş Yemek (Slow Food) Hareketinin Yerli Turistler (Akademisyenler) Tarafından Algılanışı" başlıklı makalesi nitel araştırma yöntemiyle hazırlanan ve Slow Food Hareketi'ni turistlerin bakış açısıyla değerlendiren bir çalışmadır. Fusté-Forné ve Jamal'ın (2020) "Slow Food Tourism: An Ethical Microtrend for the Anthropocene" adlı çalışması sürdürülebilirliği ve iklim değişikliğini ele alarak Slow Food Turizmi'ni tartışmayı amaçlamaktadır. Slow Food Hareketi'ni 
farklı açılardan ele alan çalışmalar da mevcuttur. Bu kaynaklardan biri olan Bratec'in (2012) "Sustaining through Gastronomy: The Case of Slow Food Movement in Slovenia, its Impacts on Socio-cultural Environments and Tourism Development" adlı araştırması Slow Food'un sosyo-kültürel ortamlara ve turizmin gelişmesine etkisini incelemektedir. Gezeroğlu'nun (2013) çalışması "Sivil Toplum Kuruluşları Kampanyalarında Medyanın Rolü Slow Food/Fikir Sahibi Damaklar İstanbul Lüfere Hasret Kalmasın Kampanyasının İncelenmesi” başlığını taşımaktadır ve bu başlık altında Slow Food'un Türkiye'deki gelişimine de değinilmektedir. Aytimur'un (2015) çalışmasında ise Slow Food'un beslenme üzerine etkileri Seferihisar ve Halfeti örnekleriyle incelenmiştir. Meriç'in (2016) yaptı̆̆ çalışmada Slow Food ve yemek turizmi Foça Yeryüzü Pazarı özelinde bir araya getirilmiştir. Özkan, Curkan ve Nisari'nin (2016) yapmış olduğu çalışma Slow Food ve Germiyan'ı aynı başlık altında incelemekle birlikte temelde Germiyan Festivali'ni ele almaktadır. Özer (2019) “Slow Food'a İlişkin Turist Motivasyonlarının Tekrar Ziyaret Etme Niyetine Etkisi: Germiyan Köyü Örneği” başlı̆̆ı altında Slow Food Hareketi ve turist motivasyonu arasındaki ilişkiyi incelemiştir. Bacakoğlu (2019) “Türkiye'de Kır-Kent Çelişkisi Bağlamında Yavaş Yemek Hareketi: Germiyan Örneği" çalışmasında konuyu kır ve kent karşıtlı̆̆ değerlendirmiştir. Yazar (2019) "Gökçeada'nın Gastronomi Rotalarında Slow Food ve Gastronomi Turizmi" ismini taşıyan çalışmasında Slow Food Hareketi ve gastronomi turizmini bir arada incelemiştir. Benzer şekilde Aliyeva (2020) "Slow Food Hareketinin Gastronomi Turizminin Sürdürülebilirliği ile İlişkisi: Foça Örneği” adlı bir çalışma yapmıştır. Kocabaş (2020) "Slow Food Hareketi'ne Yönelik Etnografik Bir Araştırma: Germiyan Köyü Örneği” başlıklı çalışmasında Germiyan'ın turizm köyüne dönüşme sürecini ele almıştır. Mevcut araştırmalardan farklı olarak bu çalışmada sürdürülebilir turizm ve Slow Food Germiyan özelinde bir araya getirilmiştir ve nitel araştırma yöntemi kullanılarak köy halkının görüşleri doğrultusunda Slow Food ve turizmin etkileri kapsamlı bir şekilde araştırılmıştır.

\section{Yöntem}

\subsection{Araştırmanın Tasarımı}

Nitel çalışma modeli olarak tasarlanan bu araştırma Slow Food Hareketi'nin sürdürülebilir turizm hareketi olarak değerlendirilmesini kapsamaktadır. Bu bağlamda Slow Food Hareketi'nin kültürel, sosyal, ekonomik yapıya ve turizm hareketliliğine etkisi incelenmiştir. Germiyan özelinde yapılmış, çalışmaların sınırlılığı çalışmanın özgünlüğünü artırmıştır ve literatüre farklı bakış açısı sunmuştur. Bu doğrultuda soru cetveli özgün bir şekilde hazırlanmıştır. Yarı yapılandırılmış hazırlanan görüşme soruları, uzman bir akademisyen tarafından değerlendirilmiştir. Değerlendirme sonrası sorulara son hali verilmiştir.

Görüşmeler, öncelikle Germiyan'ın yerel halkıyla yapılmıştır. Ardından Slow Food Hareketi'ne öncülük eden Çeşme Rotary Kulübü eski üyeleri ile gerçekleştirilmiştir. Bu görüşmeler toplamda iki hafta sürmüştür. Araştırma alanının iyi tanınması çalışma sürecinin daha verimli geçmesini sağlamıştır. Beşinci Germiyan Festivalinde ve görüşmeler esnasında gözlemler yapılmıştır. Yapılan gözlemlerin ana amacı festival süresince ve festival dışında köy sakinlerinin ziyaretçilere karşı sözlü ve sözlü olmayan tutumlarının, satış yapan ve işletme sahibi olan bireylerin davranışlarının incelenmesi ve karşılıklı iletişimlerin gözlemlenmesidir. Görüşme ve gözlem tekniklerinin bir arada kullanılması araştırmanın geçerliliğini ve güvenirliliğini artırması açısından da önemlidir.

\subsection{Veri Toplama Araçları}

Durum çalışmalarında bir veri toplama aracının yeterli olmasının yanı sıra birden fazla veri toplama aracının kullanılarak veri zincirinin oluşturulması çalışmanın yapısını güçlendirir ve çalışmaya olumlu bir katkı sağlar (Seggie ve Bayyurt, 2017; Yıldırım ve Şimşek, 2018; Creswell, 2018). Bu durum göz önünde bulundurulduğunda bu çalışmada yarı yapılandırılmış görüşme ve yapılandırılmamış gözlem olmak üzere iki farklı teknik kullanılmıştır.

\subsection{Yarı Yapılandırılmış Görüşme}


Sürdürülebilir turizm hareketiyle Slow Food Hareketi'nin Germiyan özelinde bağdaştırılmasında derinlemesine bir araştırma yapabilmek için yarı yapılandırılmış, görüşme tekniğinin uygulanmasına karar verilmiştir. Bu sayede diğer tekniklere oranla birden fazla kategoride ölçüm yapma ve çalışma sorularında yer almayan bilgilere ulaşma şansı elde edilmiştir. Çalışmada bu tekniğin tercih edilmesinin başlıca nedenleri, çalışmaya derinlik kazandırması, çalışmanın çok yönlü olmasını sağlaması ve görüşme yapılan kişilerin verdiği cevaplara göre çalışmayı yönlendirmesidir.

Çalışma esnasında soruların sıralaması konuşmanın gidişatına uygun olarak değiştirilmiş ve kimi görüşmelerde bazı soruların sorulması gerekli görülmemiştir. Soru cetvelinde demografik sorularla birlikte toplam beş ayrı bölüm ve bölümlerin alt soruları olmak üzere toplamda kırk beş soru hazırlanmıştır. Ana bölümlerde Germiyan özelinde sorular, yerel halkın yemek ve mutfak kültürü, Slow Food üzerine bilgilerin ölçülmesi, son olarak da turizme ve Germiyan Festivaline yönelik tutumlar yer almıştır. Sorular tekniğin yapısına uygun olarak kısa ve anlaşılır nitelikte hazırlanmıştır. Sorular cevaplanırken kimi soruların cevapları diğer soruları kapsayacak nitelikte olmuştur.

Çalışmanın verileri 21 Nisan - 1 Mayıs 2019 tarihleri arasında Çeşme ve Germiyan'da yapılan görüşmelerden elde edilmiştir. Görüşmeler öncesinde, görüşme yapılacak kişiler ile tarih ve saat belirlenmiştir ve görüşmecilerin istedikleri noktalarda yüz yüze görüşme gerçekleştirilmiştir. Bu sayede kişilerin kendilerini rahat hissetmesi sağlanmıştır. Tüm görüşmeler iki araştırmacı tarafından yürütülmüştür. Görüşmeye başlamadan önce kişiler çalışma hakkında bilgilendirilmiştir ve izinleri doğrultusunda ses kaydı alınmıştır. Ses kayıtlarının çalışmada elde edilecek bulgular dışında herhangi bir yerde yayınlanmayacağ 1 garanti edilmiştir ve karşılıklı güven sağlanmıştır. Geriye dönük veri kaynağ olması açısından kayıtlar arşivlenmiştir ve gizlilik esasları dikkate alınmıştır. Sorular ortalama 30 dakika sürecek şekilde hazırlanmıştır. Ancak görüşme esnasında konuşmaların gidişatı farklı noktalara da değindiği için katılımcılar ile 32-71 dakika arasında görüşülmüştür. Sorulara geçilmeden önce yapılan sohbetlerde görüşme sorularıyla benzer konular konuşulmuştur ve görüşme esnasında sorular tekrar sorulduğunda cevapların aynı olduğu teyit edilmiştir. Araştırmacılar soruların cevaplanması aşamasında katılımcıları yönlendirecek tutumlardan kaçınmıştır. Her katılımcıya sorular aynı tutum ve davranışla yöneltilmiştir.

\section{4.Çalışma Grubu}

Araştırmanın çalışma grubunu Germiyan'da ikamet eden ve köydeki tüm süreçleri deneyimlemiş olan kişiler ve Çeşme' de ikamet eden, Slow Food sürecinin oluşmasına öncülük etmiş, turizm faaliyetlerinin gelişmesine destek veren kişiler oluşturmuştur. Verilerin birbirini tekrarlamaya başladığı noktada görüşmeler Germiyan'dan sekiz, Çeşme' den iki kişi olmak üzere on kişi ile sonlandırılmıştır. Çalışma hem Slow Food'u deneyimleyenler hem de Slow Food'a öncülük eden kişilerle yapıldı̆̆ 1 için farklı görüşme gruplarına uygulanmıştır. Böylece bulguların farklı kaynaklardan alınıp, uyumluluğunun ölçülmesi sağlanmıştır.

Kişiler ölçüt örnekleme yöntemi ile saptanmıştır. Bu örnekleme yönteminde önceden belirlenen ölçütler doğrultusunda ölçütü karşılayan durumlar çalışılır (Yıldırım ve Şimşek, 2018). Yapılan çalışmada ise bu ölçütün kapsamı Germiyan'da Slow Food sürecini yakından deneyimlemiş ve turizm faaliyetlerinin içerisinde bulunan kişilerin saptanmasıyla belirlenmiştir. Çalışma grubunun demografik özelliklerinin dağılımı Tablo 1'de verilmiştir.

Tablo 1. Çalışma Grubunun Demografik Özellikleri

\begin{tabular}{|l|l|l|l|c|}
\hline \multicolumn{1}{|c|}{ Kişiler } & Cinsiyet & Yaş & Yer & Ĕ̈itim \\
\hline Katılımcı 1 & Kadın & 57 & Germiyan & Ön lisans \\
\hline Katılımc1 2 & Erkek & 58 & Germiyan & Doktora \\
\hline Katılımc1 3 & Erkek & 62 & Germiyan & Lisans \\
\hline Katılımc1 4 & Kadın & 55 & Germiyan & Lise \\
\hline
\end{tabular}


Demir, B. (2021). Sürdürülebilir Turizm Hareketi Olarak Slow Food: Germiyan Örneği. GSI Journals Serie A: Advancements in Tourism, Recreation and Sports Sciences (ATRSS), 4 (2): 1-16

\begin{tabular}{|l|l|l|l|c|}
\hline Katılımc1 5 & Kadın & 60 & Çeşme & Yüksek Lisans \\
\hline Katılımcı 6 & Kadın & 63 & Çeşme & Yüksek Lisans \\
\hline Katılımcı 7 & Kadın & 53 & Germiyan & Lisans \\
\hline Katılımc1 8 & Erkek & 54 & Germiyan & Lisans \\
\hline Katılımc1 9 & Kadın & 55 & Germiyan & Lise \\
\hline Katılımcı 10 & Kadın & 49 & Germiyan & İlkokul \\
\hline
\end{tabular}

\subsection{Yapılandırılmamış Gözlem}

Gözlem, kişilerin gözlemlenebilir davranışlarının, deneyimlerinin ve diğer insanlarla olan etkileşimlerinin veri olarak kullanılması şeklinde tanımlanabilir (Seggie ve Bayyurt, 2017). Söz konusu tekniğin kullanılmasının güçlü yönleri olarak sözel olmayan davranışların ortaya çıkmasına olanak vermesi, doğal çevrede gerçekleşmesi, uzun tutulabilir ve zamana yayılabilir olması gösterilebilir (Yıldırım ve Şimşek, 2018).

Gözlem tekniği kendi içinde farklı çeşitlere ayrılır. Çalışmada kullanılan türü ise yapılandırılmamış gözlem tekniğidir. Kişilerin davranışlarının gözlemlenebildiği doğal ortamda kültürün içine girebilmek, böylece çalışılan kültür ve alt kültürlerin detaylı bir biçimde tanımlanabilmesi için katılımcı gözlemci olarak yer almak faydalı görülmüştür.

Gözlemler sırasında, gözlemin amacı, gözlemlenecek mekânlar ve kişiler belirlenmiştir. Yapılan gözlemlerin amacı festival süresince ve festival dışında köy sakinlerinin ziyaretçilere karşı sözlü ve sözlü olmayan tutumlarının incelenmesi, satış yapan ve işletme sahibi olan bireylerin davranışlarının incelenmesi ve karşılıklı iletişimlerin gözlemlenmesidir.

Yapılandırılmamış gözlem tekniği Beşinci Germiyan Festivali ve köyde yapılan görüşmeler esnasında kullanılmıştır. Festivalin yapıldığı iki günlük süreç ve görüşmelerin yapıldı̆̆ 1 iki haftalık zaman diliminde Germiyan'da uygulanmıştır. Festival süresince insanların en çok etkileşimde bulunduğu mekânlar arasında yer alan; tezgâhların bulunduğu köy meydanı, köy kahvehanesi ve köyde bulunan işletmeler odak noktası olarak kullanılmıştır. Gözlem süresince köy sakinlerinin ve ziyaretçilerin davranışları araştırmacı tarafından not edilmiştir. Bu notlar gözlemin yapıldığı mekâna ve tarihe göre düzenlenip arşivlenmiştir. Gözlem için kullanılan süre festival süresince en az altı, en çok sekiz saat iken; kullanılan mekân özeline indirgendiğinde en az bir, en çok üç saat olmuştur. Görüşme süresince yapılan gözlemler en az otuz dakika, en çok bir saat sürmüştür.

\subsection{Veri Analizi}

Veri toplama işlemi esnasında ses kaydedici ile kaydedilen görüşmeler veri analizi için bilgisayara aktarıldıktan sonra tarihlere ve katılımcılara göre ayrılarak dosyalanmıştır. Bu ses kayıtları alanında deneyimli bir araştırmacı tarafından analiz edilmiştir ve yazıya aktarılmıştır. Görüşmeler ve gözlemlerden elde edilen veriler analiz edilirken betimsel analiz tekniğine başvurulmuştur. Bu teknikte temel amaç elde edilen verilerin daha önce belirlenen temalara göre özetlenip yorumlanması ve bulguların okuyucuya sunulmasıdır. Betimsel analiz tekniği içerisinde dört aşamayı barındırır: (1) Analiz için çerçeve oluşturma; (2) Tematik çerçeveye göre verilerin işlenmesi; (3) Bulguların tanımlanması; (4) Bulguların yorumlanması (Yıldırım ve Şimşek, 2018). Bu doğrultuda betimsel analiz yapılırken katılımcıların görüşleri doğrudan alıntılarla aktarılmıştır. Çalışmanın geçerliği açısından bu analiz tekniği önem arz etmiştir. Çalışmanın güvenirliği için ses kayıtlarının ham hali başkaları tarafından incelenebilecek şekilde depolanıp saklanmiştır.

Yapılan alan çalışmasından elde edilen veriler tematik bir çerçeveye göre işlenmiştir ve çalışmanın amacına uygun olan veriler bir araya getirilmiştir. Sonraki aşamada ise veriler tanımlanmıştır ve gerekli yazım düzenlemeleri yapılarak bulgular kısmında aktarılmıştır. Verilen yorumlanması ise sonuç kısmında yer almıştır. Verilerin analizi esnasında çerçeve doğrultusunda görüşler aktarılırken temaya 
vurgu yapanların sayısı "üç katılımcı", "altı katılımcı" şeklinde belirtilmiştir. Görüşmelerden yapılan alıntılarda ise katılımcı ismi yerine, katılımcı 3 (K. 3), katılımcı 6 (K. 6) biçiminde parantez içinde kısaltma kullanılmıştır.

\section{Bulgular}

\subsection{Görüşmelerden Elde Edilen Bulgular}

Görüşmelerde elde edilen veriler aktarılırken uygulanabilirliğine göre tablolaştırma sistemi ve betimsel analiz kullanılmıştır. Bazı bölümlerde kategorilere ayrılacak biçimde soru sorulmadığı için bu kısımlarda yalnızca analiz yapılmıştır. Tablolar oluşturulurken soruların niteliğine ve verilen cevaplara göre "olumlu, olumsuz ve hem olumlu hem olumsuz; var, yok ve kısmen (var); başarılı, başarısız ve kısmen (başarılı); yeterli, yetersiz ve kısmen (yeterli)" olarak kodlanmıştır. Elde edilen bulgular dört temel başlıkta değerlendirilmiştir: (1) Yerel Halkın Germiyan'ın Değerleri Üzerine Genel Bilgisinin Ölçülmesi, (2) Yerel Halkın Yemek ve Mutfak Kültürü Üzerine Olan Algısı, (3) Yerel Halkın Slow Food Hareketi Üzerine Olan Alg1sı, (4) Yerel Halkın Turizm Faaliyetleri Üzerine Olan Algısı.

Araştırmada görüşme yapılan kişilere Germiyan'ın tarihini, kökenini, tarımsal faaliyetlerini ve yemeklerini içeren sorular sorulmuştur ve bu şekilde yerel halkın yaşadıkları yer hakkında ne kadar bilgi sahibi olduklarının ölçülmesi amaçlanmıştır. Buna ek olarak aynı sorular Çeşme' de yapılan görüşmelerde de tekrarlanmıştır ve köyde çeşitli girişimlerde bulunan kişilerin köy hakkında ne kadar bilgi sahibi olduğunun saptanması hedeflenmiştir.

Germiyan hakkındaki soruları cevaplayan katılımcılardan sekizi Germiyan'ın tarihi hakkında net bir bilgi sahibi değildir. Bir katılımcı "Köyün tarihi üzerine farklı görüşler var ancak ben Osmanlıdan önce veya Osmanlı döneminde kurulduğunu düşünüyorum. Germiyanoğluları Kütahya'dan göç etmişler ancak beylik hakkındaki bilgilerim ortaokul ve lisede öğrendiklerimle sınırlı." (K. 1) şeklinde görüş belirtmiştir.

Tarımsal faaliyetler ve yemekler konusunda ise katılımcların tamamı yeterli bilgiye sahiptirler. Yapılan görüşmelerde özellikle Germiyan'da susuz tarım uygulandığını, Germiyan'da yetişen kınalı bamya ve kavunun ön planda olduğunu vurgularken; zeytinciliğin önemli bir geçim kaynağı olduğunun altını çizmişlerdir. Bir katılımcı "Burası bir Ege köyü olduğu için ot ağırlıklı yemekler daha fazla ve çalkama bunlardan birisi. Kavun, domates ve kınalı bamya burada yoğun olarak yetişiyor. Zeytincilik de önemli bir geçim kaynağı olarak kullanılıyor." (K. 4) demiştir.

Araştırmada yerel halkın geçmişle bugünü karşılaştırdıklarında yemek ve mutfak kültürlerinde ne gibi farklar olduğunun, özel günlerde ve günlük yemek düzenlerinde farklılıklar olup olmadığının ve geleneksel yemeklerin devamlılığının ortaya çıkarılması amaçlanmıştır. Bunlara ek olarak kış için ne gibi hazırlıklar yaptıkları ve bu sorunun içerisinde yer alan mevsiminde sebze-meyve tüketimi araştırılmıştır. Görüşme yapılan kişilerden sekizi geçmişle bugün arasında yemek ve mutfak kültürlerinde değişikler olduğunu ifade etmiştir. Bir katılımcı görüşü, "Benim çocukluğumda ve gençliğimde yemek ocakta pişirilir, sofra aynı yere kurulur, sofra kalktığında ise yataklar serilirdi. Bunların hepsi aynı mekân içerisinde gerçekleşirdi. Fakat bugün salonda yemek masasında oturuyoruz." (K. 2) şeklindedir.

Elde edilen verilere göre kişilerin tamamı kış için hazırlık yaptığını ve mecbur kalınmadığı sürece mevsimi dışında ürün almamaya özen gösterdiğini söylemiştir. Bir katılımcının ifadesi "Kış için birçok hazırlık yapıyorum. Salçamı kendim yaparım, yazın domates konserveleri hazırlarım ve bunlara ek turşu, reçel, tarhana gibi ürünleri de kış için hazırlarım." (K. 4) yönündedir.

Geleneksel yemeklerin devamlılığı konusunda ise katılımcılardan üçü geleneksel yemekleri yapmayı bilmediğini belirtirken yedisi yemeklerin gelecek nesillere aktarılmasını sağladığını ve bu yemekleri günlük hayatlarında dahi yaptığını belirtmiştir. Katılımcılardan ikisi, "Geleneksel yemeklerin bir kısmını yapmayı biliyorum fakat örneğin hayatımda hiç bazina yapmadım, yapmayı da bilmiyorum." (K. 1); "Geleneksel yemekleri yapmaya ve bunları başkalarına aktarmaya özen gösteriyorum. Misafirlerim için 
de bu yemekleri yapmaya dikkat ediyorum, unutulmaması gerektiğini düşünüyorum." (K. 4) şeklinde görüş belirtmiştir.

Bu çalışmada ayrıca yerel halkın Slow Food hakkında bilgi sahibi olup olmadığına, köyde bu konuda ne kadar bilgilendirme yapıldığına, Germiyan'da Slow Food hareketiyle birlikte nelerin değiştiğine, Slow Food'un katkı ve zararlarına, hareketin başarılı mı başarısız mı olduğuna ve bunun nedenlerine yer verilmiştir. Slow Food hakkındaki genel bilgilerin ölçümünden elde edilen bulgular Tablo 2' de görülebilir.

Tablo 2. Yerel Halkın Slow Food Hakkında Bilgilerinin Ölçülmesi

\begin{tabular}{|l|l|l|l|l|l|l|l|l|l|l|l|}
\hline Kat1lımc1lar/Görüşler & K1 & K2 & K3 & K4 & K5 & K6 & K7 & K8 & K9 & K10 & TOPLAM \\
\hline Var & X & X & & & X & X & X & X & & & 6 \\
\hline K1smen & & & X & X & & & & & X & & 3 \\
\hline Yok & & & & & & & & & & X & 1 \\
\hline
\end{tabular}

Verilerden elde edilen bilgiler doğrultusunda Slow Food'u altı katılımcının bildiği, üç katılımcının bu konudaki bilgisinin eksik olduğu, bir katılımcının bilmediği sonucuna varılmıştır. İki katılımcı, "Kurucusunun kim olduğunu hatırlamıyorum ancak doğal ve temiz beslenmeye yönelik bir hareket olarak İtalya' da ortaya çıktığını biliyorum." (K. 3); “Endüstriyelleştirilmiş, gıdalara karşı oluşturulmuş, ve yerel ürünleri destekleyen bir harekettir. İtalya' da Carlo Petrini tarafından ortaya çıkarılmıştır." (K. 2) şeklinde görüş belirtmiştir.

Germiyan'da Slow Food Hareketi ile birlikte ne gibi değişiklikler olduğu ve turizme olan etkisi konusunda ise katılımcılardan yedisi olumlu değişiklikler olduğunu ifade ederken, üç katılımcı olumluların yanı sıra olumsuz değişikliklerin de olduğunu belirtmiştir ve hiçbir katılımcı olumsuz etkisinin olduğunu ifade etmemiştir. Katılımcı görüşleri şu şekildedir: "Slow Food Germiyan için çok büyük bir reklam aracı oldu ve Türkiye'de köyün tanınmasını sağladı. Her yerden ziyaretçi gelmeye başladı." (K. 5); "Slow Food ile birlikte insanlarda para kazanma duygusu oluştu, bu da yöresellikten uzaklaşmalarına neden oldu. Ancak sosyal açıdan katkı sağladı. Önceden birbirlerine sadece selam veren insanlar toplantılarla birlikte daha yakın olmaya başladılar." (K. 2). Tablo 3'te elde edilen bulgular yer almaktadır.

Tablo 3. Germiyan'da Slow Food Hareketinin Etkisi Üzerine Algilar

\begin{tabular}{|l|l|l|l|l|l|l|l|l|l|l|l|}
\hline Katılımcılar/Görüşler & K1 & K2 & K3 & K4 & K5 & K6 & K7 & K8 & K9 & K10 & TOPLAM \\
\hline Olumlu & X & & X & X & X & & X & X & & X & 7 \\
\hline Olumsuz & & & & & & & & & & & 0 \\
\hline $\begin{array}{l}\text { Hem Olumlu Hem } \\
\text { Olumsuz }\end{array}$ & & X & & & & X & & & X & & 3 \\
\hline
\end{tabular}

Slow Food'un köyde başarılı olup olmadığı yönündeki soruya verilen cevaplarda katılımcılardan sekizi bu hareketin başarısız olduğunu belirtmiş, biri başarılı olduğunu dile getirmiştir. Kısmen başarılı olduğu görüşünde olan katılımcı sayısı ise bir kişidir. Katılımcılar "Köy bazında Slow Food'un uygulanması çok zor çünkü denetleme imkânı kısıtlı. Slow Food'un Türkiye ayağı ve yerel yönetim yeterince destek vermedi. İnsanlar köyün tanıtımı için bu işe girdiler fakat gereklilikleri yerine getirmediler." (K. 2), "Mekânların 12 ay açık tutulmaması başarısız olmasının nedenlerinden biri ancak diğer bir neden de hırsın aklın önüne geçmesi oldu. İnsanlar kısa yoldan, kısa zamanda para kazanmak istedi fakat Slow Food uzun vadede sonuçları alınabilecek bir harekettir." (K. 5), "Nereden baktığınıza göre değişir. Eğer yaşam felsefesi olarak benimsediyseniz başarılı oldu fakat bunu göstermelik yaptıysanız başarısız oldu. Ayrıca buradaki ürünlerin tanıtımı konusunda da olumlu bir etkisi oldu." (K. 3) ifadelerini kullanmıştır. Tablo 4 'te yer alan veriler varılan bulguları göstermektedir. 
Demir, B. (2021). Sürdürülebilir Turizm Hareketi Olarak Slow Food: Germiyan Örneği. GSI Journals Serie A: Advancements in Tourism, Recreation and Sports Sciences (ATRSS), 4 (2): 1-16

Tablo 4. Slow Food'un Germiyan'daki Başarı Durumuna Yönelik Algılar

\begin{tabular}{|l|l|l|l|l|l|l|l|l|l|l|c|}
\hline Katılımc1lar/Görüşler & K1 & K2 & K3 & K4 & K5 & K6 & K7 & K8 & K9 & K10 & TOPLAM \\
\hline Başarılı & & & & X & & & & & & & 1 \\
\hline Kısmen & & & X & & & & & & & & 1 \\
\hline Başarısız & X & X & & & X & X & X & X & X & X & 8 \\
\hline
\end{tabular}

Turizmin Germiyan üzerindeki etkisi araştırıldığında katılımcılardan üu̧ü sosyal ve ekonomik açıdan olumlu katkı sağladığını ifade ederken, yedisi hem olumlu hem de olumsuz etkilerinin olduğunu ifade etmiştir. Katılımcı görüşleri, “Köy gezilerinin artmasıyla Germiyan da turlar kapsamında yer almaya başladı. Köyün tanıtımı açısından olumlu ancak turist açısından bakıldığında olumsuz bir durum ortaya çıkıyor. Köyde turiste yönelik yeterince hazırlık yok.” (K. 2), “Turizm Germiyan'ın bir rant alanı olarak görülmesine neden olmaya başladı ve köylünün bu konuda bilinçli olması gerekiyor. Ancak turistlerin gelmesi köyün kalkınması için önemli bir araç." (K. 5) şeklindedir. Tablo 5'te verilerden elde edilen bulgular yer almaktadir.

Tablo 5. Turizmin Germiyan Üzerindeki Etkisi

\begin{tabular}{|l|l|l|l|l|l|l|l|l|l|l|l|}
\hline Katılımcılar/Görüşler & K1 & K2 & K3 & K4 & K5 & K6 & K7 & K8 & K9 & K10 & TOPLAM \\
\hline Olumlu & X & & X & & & & & & & X & 3 \\
\hline Olumsuz & & & & & & & & & & & 0 \\
\hline $\begin{array}{l}\text { Hem Olumlu Hem } \\
\text { Olumsuz }\end{array}$ & & X & & X & X & X & X & X & X & & \\
\hline
\end{tabular}

Germiyan'da turizmin geliştirilmesi için yapılması gerekenler ise katılımcılar tarafından şu şekilde ifade edilmiştir; "Hizmet sektöründe genç insanların çalışması lazım ancak burada genç nüfus çok az.” (K. 1), "Satılan ürünlerin daha nitelikli olması ve fiyatların düşük tutulması gerekli." (K. 2), "Daha fazla insan evini turistlere açmalı." (K. 3), "Ev pansiyonculuğu konusunda eğitim verilmeli ve bir kooperatif hareketiyle Germiyan'a özgü ürünlerin marka haline getirilip pazarlanması gerekli." (K. 5).

Köyde turizm hareketliliği yaratan Germiyan Festivalinin köye olan katkıları ve zararları yönündeki sorular ise tüm katılımcılar tarafından katkı sağladığı herhangi bir zararının olmadığı şeklinde cevaplanmıştır ve tüm katılımcılar festivalin devam etmesini istediklerini ifade etmiştir. "Festivalin devam etmesi lazım, diğer günlerde aktif olmayan insanlar yılda bir kez de olsa kazanç elde ediyor." (K. 1), "Festival bölgedeki en başarılı etkinliklerden biri oldu. Tarihi, kültürel ve gastronomik açıdan zengin bir içeriğe sahip, bence devam etmesi gerekir." (K. 2) yönünde görüş belirten katılımcıların yanı sıra diğer katılımcılar düşüncelerini "Germiyan Festivali kesinlikle devam etmeli, festival sayesinde el emekleri sergileniyor. Bu emekler göz önünde bulundurulduğunda yerel halk dışında kimsenin satış yapamaması olumlu katkı sağlıyor." (K. 3), "Maddi katkısını bir yana bırakırsak, festival süresince kurulan atölyeler sayesinde köyün unutulmaya yüz tutmuş değerleri hatırlanıyor." (K. 7) şeklinde aktarmıştır.

Festivalin tanıtımının yeterliliğini ölçmeye yönelik sorulan soru katılımcıların sekizi tarafından yetersiz olduğu yönünde cevaplanırken, biri yeterli, biri kısmen yeterli olduğunu belirtmiştir. Tanıtım ve desteğin yetersiz olduğunu düşünen bir katılımcının görüşü “Tanıtımın yetersiz olduğunu düşünüyorum, çoğu insan burada festival olduğundan haberdar değil. Belediye yeterince katkı da sağlanmıyor, etkinlikler bizim çabalarımızla yürüyor." (K. 1) şeklindedir, diğer katılımcılar ise "Belediye tanıtım için çok geç hareket ediyor ve yeterince destek vermiyor." (K. 2), "Sosyal medyada yapılan paylaşımlar sayesinde 
Demir, B. (2021). Sürdürülebilir Turizm Hareketi Olarak Slow Food: Germiyan Örneği. GSI Journals Serie A: Advancements in Tourism, Recreation and Sports Sciences (ATRSS), 4 (2): 1-16

diğer insanlar da görüp geliyorlar ama daha iyi tanıtım yapılabilir." (K. 9) ifadelerini kullanmışlardır. Tablo 6'da elde edilen bulgular görülmektedir.

Tablo 6. Germiyan Festivali Tanıtımının Yeterliliği Üzerine Görüşler

\begin{tabular}{|c|c|c|c|c|c|c|c|c|c|c|c|}
\hline Katılımcılar/Görüsşler & K1 & $\mathrm{K} 2$ & K3 & K4 & K5 & K6 & K7 & K8 & K9 & K10 & TOPLAM \\
\hline Yeterli & & & X & & & & & & & & 1 \\
\hline Kismen & & & & & & & & & $X$ & $X$ & 1 \\
\hline Yetersiz & $X$ & $X$ & & $X$ & $X$ & $X$ & $X$ & $X$ & $X$ & $X$ & 8 \\
\hline
\end{tabular}

\subsection{Gözlemlerden Elde Edilen Bulgular}

Çalışmanın konusu kapsamında 6-7 Ekim 2018 tarihleri arasında gerçekleşen Beşinci Germiyan Festivalinde yerel halkın ve gelen ziyaretçilerin birbirleriyle olan etkileşimleri, tavır ve tutumları gözlemlenmiştir. Germiyan Festivali kapsamında kurulan stantlar köy meydanında yer almaktadır. Dolayısıyla festivalin ana merkezini bu meydan oluşturmaktadır. Burası köylüler ve ziyaretçiler arasında en çok temasın gerçekleştiği alan olarak önem teşkil etmektedir. Festival süresince yapılan gözlemlerde yerel halkın stantlarda ziyaretçilere karşı güler yüzlü ve yardımsever oldukları, ziyaretçilerin köylülere karşı olan tavır ve tutumlarının genel çerçeve itibariyle olumlu olduğu, yalnızca bazı ziyaretçilerin fiyatlar konusunda memnuniyetsiz oldukları gözlemlenmiştir.

Köyün girişinde yer alan ve ziyaretçilerin ilk karşılaştıkları mekân olan köy kahvehanesinde yapılan gözlemlerde ise ziyaretçiler ve köylüler arasındaki etkileşimin kuvvetli olduğu, birbirleriyle temastan kaçınmadıkları bulgusuna ulaşılmıştır. İşletmelerde yapılan araştırmalarda işletme sayısının az olması ve oluşan yoğunluk nedeniyle birtakım aksaklıkların yaşandığı, bazı ziyaretçilerin bu durumu olumsuz karşıladığı ancak genel itibariyle hem ziyaretçiler hem de işletme sahipleri tarafından iletişimi bozacak herhangi bir davranışın sergilenmediği, sözlü veya sözlü olmayan çatışmaların yaşanmadığı görülmüştür.

Festival süresince bu mekânlar dışında da herhangi bir çatışma, iletişim bozukluğu, olumsuz tavır ve tutum gözlemlenmemiştir. Köy sakinleri genel olarak ılımlı, hoşgörülü, yardımsever ve misafirperver davranmıştır. Yalnızca gelen ziyaretçilerin bir kısmının çevre konusunda hassas olmadıkları, hem çevre hem de gürültü kirliliğine sebebiyet verdikleri, özel mülke saygı duymadıkları gözlemlenmiştir. Ziyaretçilerin Slow Food Hareketi hakkında bilgi sahibi olmadıkları, bu konuda da köyde yeterince bilgilendirici levhanın olmaması gözlemler arasında yer almıştır. Ziyaretçilerin en çok ilgi gösterdiği unsur ise duvar resimleri olmuştur.

Yarı yapılandırılmış görüşme tekniğinin uygulanırken aynı zaman diliminde yapılandırılmamış gözlem tekniği de kullanılmıştır. Germiyan'da bulunulan iki haftalık süreçte yerel halk ve ziyaretçiler arasındaki etkileşim, birbirlerine karşı tavır ve tutumları gözlemlenmiştir. Görüşmelerin büyük çoğunluğu işletme olarak kullanılan yerlerde gerçekleştirildiği için yapılan gözlemlere pozitif katkısı olmuştur. Isşletmelerde bulunulan süre dâhilinde gelen ziyaretçiler güler yüzle karşılanmıştır ve olumsuz herhangi bir tavır sergilenmemiştir. Bazı işletme mekânlarında kişiler ziyaretçilerle birebir temas içerisinde olmuştur. Ziyaretçiler tarafından olumsuz karşılanan tek şeyin köyde yerel ürünleri temin edebilecekleri bir pazarın eksikliği olduğu bulgusu elde edilmiştir. Festival süresince gözlemlendiği gibi festival dışındaki günlerde de ziyaretçilerin ilgisini en çok çeken şey duvar resimleri olmuştur.

\section{Sonuç, Tartışma ve Öneriler}

Slow Food Hareketi'nin Germiyan'da turizm ve günlük yaşam üzerindeki etkisinin araştırıldığı bu çalışmada, hareketin turizme katkısının olduğu ve köy bazında değerlendirildiğinde yerel halk üzerinde olumlu etki yarattığı sonucu elde edilmiştir. Yapılan çalışmada yerel halkın yaşadıkları yerin tarihi hakkında tam olarak bilgi sahibi olmadığı sadece kısa bilgiler verebildikleri, bunun aksine görüşülen 
kişilerin tarımsal faaliyetler ve yemekler konusunda yeterli düzeyde bilgi sahibi oldukları yönünde tespitler yapılmıştır. Geçmişle günümüz arasındaki yemek ve mutfak kültürü kıyaslandığında ise günümüzün getirdiği şartlar doğrultusunda birtakım değişikler olduğunu, eski köy yaşantısının terk edildiğini ancak geleneksel yemeklerin halen pişirildiğini ve gelecek nesillere aktarıldığını söylemek mümkündür. Bu kapsamda değerlendirildiğinde köyde yaşayanların sahip oldukları değerleri ellerinden geldiğince korumaya ve sürdürmeye çalıştıkları söylenebilmektedir.

Slow Food Hareketi'nin yarattığı olumlu etkiler dikkate alındığında, hareket sayesinde köyün tanıtımının sağlandığı ve bu sayede daha çok insan tarafından ziyaret edildiği vurgulanabilir. Ayrıca Slow Food Hareketi'nin, köylülerin yemek kültürlerinin hâlihazırda doğal ve sağlıklı gıdalar üzerine kurulu olması nedeniyle yemek kültürü üzerinde etki yaratmasa da sosyal ve ekonomik hayat açısından etkili olduğu belirtilebilir. İnsanların birbirleriyle daha samimi ilişkiler kurmasını ve ekonomik açıan kalkınmayı sağlamaktadır. Ek olarak yıllarca yalnızca bir geçiş güzergâhı olarak kullanılan köy, Çeşme Yarımadası sınırlarında bulunan diğer yerler gibi turizmin bir parçası haline gelmiştir.

Slow Food Hareketi'nin köyde yarattığı olumlu etkiler bir kenara bırakıldığında, hareketin herkes tarafından tam olarak anlaşılamadığı, insanların bu konudaki bilgilerinin ezbere dayalı olduğu, Slow Food felsefesinin içselleştirilemediği, mevcut düzenleriyle uyum göstermesine rağmen yaşam tarzından çok para kazanma aracı olarak görüldüğü ortaya çıkmaktadır. Ancak bu düşünce Slow hareketlerin felsefesine aykırıdır. Hareketin başarısız olduğu görüşünü belirten katılımcılar da söz konusu eksikleri vurgulamışlardır. Köydeki Slow Food çalışmaları sırasında yeterli düzeyde eğitim verilmediği, çalışmaların aceleye getirildiği ve yetkililerin bu süreçte yeterince destek vermediği anlaşılmaktadır. Köyde Slow Food Hareketi için yeterince hazırlık yapılmadan, hareketin felsefesine uygun mekânların yeterli sayıya ulaşması beklenmeden ve en önemlisi uzun vadede sonuçlarının alınabileceği ve bunun kısa yoldan para kazanma fikrine aykırı olduğu aşılanmadan çok hızlı bir şekilde Slow Food köyü olarak ilan edildiği sonucuna varılmaktadır. Bu noktada Slow Food Hareketi'nin gerektirdiği tüm eğitimler gerekirse uzun bir döneme yayılarak ancak eksiksiz bir biçimde verilmelidir. Bu eğitimler verilirken her yaş grubuna ve her eğitim seviyesine uygun ve başkalarına aktarılabilecek düzeyde olmalıdır. Kriterlerin ezberde kalmasının ötesinde bunun bir yaşam felsefesi olduğu düşüncesi her kesime aktarılmalıdır. Hareketin sonuçlarının uzun vadede alınabileceği, bunun bir para kazanma aracı olarak görülemeyeceği düşüncesi vurgulanmalıdır. Yerel yönetim ve halk iş birliği içinde hareket etmeli ve destekler eksiksiz devam etmelidir. Harekete geçilmeden önce uygulanacak bölgede gerekli hazırlıklar yapılmalıdır. Bu hazırlıklara örnek olarak; Slow Food Hareketi'ne uygun iş yerlerinin açılması ve bu iş yerlerinin 12 ay açık olmasının sağlanması, bu mekânlarda hizmet verecek kişilerin turizm sektöründe deneyimli ve eğitimli olması, bölgeye özgü geleneksel değerlerin bir araya getirilmesi ve kitaplaştırılması verilebilir.

Turizm hareketliliğine katkı sağlayan festival unsuru değerlendirildiğinde tanıtımın yetersiz olması ve yerel yönetim tarafından verilen desteğin eksik olması nedeniyle festivale katılım oranının düştüğünü söylemek mümkündür. Festival süresince yalnızca yerel halkın satış yapabilmesi ve satılan ürünlerin yerel olması ekonomik açıdan ve sürdürülebilirlik açısından önemli bir faktör olarak ortaya çıkmaktadır.

Yerel halkın turistlere ayrım gözetmeksizin en iyi şekilde ev sahipliği yaptı̆̆ı açıkça görülürken turizm adına yapılması gereken önemli girişimler söz konusudur. Bu girişimler gerçekleştiğinde, köyün mevcut turizm hareketine katkısının olacağı belirtilebilir. Bu girişimlere örnek olarak işletmelerin yanı sıra kooperatifler ve yerel pazarlar kurulması verilebilir. Bu sayede hem halkın ekonomik açıdan güçlenmesi hem de ziyaretçilerin ürün çeşitliliği üzerine algılarının oluşması sağlanabilir. Bir internet sitesi kurularak insanların ürünler ve Germiyan hakkında 7 gün 24 saat bilgi alması mümkün kılınabilir. Bu internet sitesinde yöresel ve geleneksel ürünlerin satışı da yapılabilir. Bunlara ek olarak yıl içerisinde tüketici ve üreticiyi bir araya getirecek çeşitli etkinlikler düzenlenebilir. Yine yıl içerisinde çeşitli kurslar ve lezzet eğitimleri verilebilir. Yurt dışındaki etkinliklere katılım sağlanabilir ve diğer ülkelerdeki insanlarla bir araya gelinerek fikir alışverişinde bulunulabilir. Slow Food Hareketi'nin daha iyi tanıtılabilmesi adına kamusal mekânlardan kolayca elde edilebilecek broşürler ve uygulanan bölgeyi tanitıcı kitapçıklar hazırlanabilir. Slow Food işletmelerine ve yoğun olarak kullanılan mekânlara Slow Food Hareketi'ni ve 
kriterlerini tanıtan büyük afişler asılabilir. Böylece insanlar bir Slow Food işletmesinden beklentilerinin ne yönde olması gerektiğini ve hareketin amaçlarını görebilirler.

$\mathrm{Bu}$ çalışma yalnızca yerel halkın bakış açısından ele alınmıştır. Çalışma kapsamında ziyaretçilerin görüşlerine başvurulmamıştır. Sınırlı katılımcı ile gerçekleştirilen araştırma daha fazla katılımcı ile farklı araştırma teknikleri kullanılarak yapılabilir. Gelecekte Germiyan'da ve olası Slow Food kentlerinde yapılacak çalışmalarda nitel ve nicel araştırma teknikleri birlikte kullanılarak yerel halk ve ziyaretçiler arasında karşılaştırmalı bir araştırma yürütülebilir. Bu sayede ziyaretçilerin işletmelerden ve yerel halktan beklentileri ölçülebilir, Slow Food Hareketi hakkında düşünceleri ve bilgileri araştırılabilir.

\section{Teşekkür ve Bilgi Notu}

Bu makale, Burcu Demir'in Ege Üniversitesi Sosyal Bilimler Enstitüsü’nde yazılan “Sürdürülebilir Turizm Hareketi Olarak Slow Food: Germiyan Örneği" başlıklı Yüksek Lisans tezinden derlenmiştir.

\section{Kaynaklar}

Aliyeva, N. (2020). Slow Food Hareketinin Gastronomi Turizminin Sürdürülebilirliği ile İlişkisi: Foça Örneği (Yayımlanmamış, yüksek lisans tezi). Dokuz Eylül Üniversitesi, İzmir.

Amin, S. (2017). Kapitalizmden Uygarlığa. Çev. Dönmez, Y. \& Atabağsoy, N. Yordam Kitap, İstanbul.

Aytimur, R. (2015). Slow Food Hareketinin Beslenme Alışkanlıkları ve Sağlıklı Beslenmeye Etkisi Üzerine Bir Uygulama Çalışması: Halfeti ve Seferihisar Örneği (Yayımlanmamış, yüksek lisans tezi). Mardin Artuklu Üniversitesi, Mardin.

Bacakoğlu, Ş. Ö. (2019). Türkiye'de Kır-Kent Çelişkisi Bağlamında Yavaş Yemek Hareketi: Germiyan Örneği (Yayımlanmamış, yüksek lisans tezi). Burdur Mehmet Akif Ersoy Üniversitesi, Burdur.

Bratec, M. (2012). Sustaining through Gastronomy: The Case of Slow Food Movement in Slovenia, its Impacts on Socio-cultural Environments and Tourism Development, Sustaining Quality of Life through Tourism Conference, İzmir.

Bucak, T. ve Turan, Ö. (2016). Bölge Turizmine Yeni Akımların Etkisi: Gökçeada Yavaş Yemek Örneği. Journal of Yaşar University, (11) 43: 211-219.

Creswell, J. W. (2018). Nitel Araştırma Yöntemleri: Beş, Yaklaşıma Göre Nitel Araştırma ve Araştırma Deseni Çev. Ed. bütün, M. \& Demir S. B. Siyasal Kitabevi. Ankara.

Çavuş, Ş., Kaya, B. ve Demirtaş, B. (2019). Sürdürülebilir Turizm Açısından Slow Food Hareketine Bakış ve Türkiye Uygulamaları. Sözel Bildiri, International Black Sea Coastline Countries Symposium, Batum.

Çeşme Belediyesi (2019). https://cesme.bel.tr/sayfa/9-durak-9-deneyim-458831 adresinden elde edilmiştir.

Diamond, J. (2010). Tüfek, Mikrop ve Çelik. Çev. İnce, Ü. TÜBİTAK, Ankara

Ediger, V. Ş. ve Çiftçi S. (2011). Sürdürülebilir Kalkınmanın İki Temel Unsuru: Enerji ve Çevre.( 26.02.2019): http://www.eniva.org.tr/sysimg/dosya/2462013145316984.pdf

Fusté-Forné, F. ve Jamal, T. (2020). Slow Food Tourism: An Ethical Microtrend for the Anthropocene, Journal of Tourism Futures, (6) 3: 227-232.

Garrod, B. ve Fyall, A. (1998). Beyond The Rhetoric of Sustainable Tourism?. Tourism Management, 19 (3): 199-212.

Gezeroğlu, E. (2013). Sivil Toplum Kuruluşları Kampanyalarında Medyanın Rolü Slow Food/Fikir Sahibi Damaklar “İstanbul Lüfere Hasret Kalmasın” Kampanyasının İncelenmesi (Yayımlanmamış, yüksek lisans tezi). İstanbul Üniversitesi, İstanbul. 
Demir, B. (2021). Sürdürülebilir Turizm Hareketi Olarak Slow Food: Germiyan Örneği. GSI Journals Serie A: Advancements in Tourism, Recreation and Sports Sciences (ATRSS), 4 (2): 1-16

Gezgin, I. (2019). Çeşme-Alaçatı: Arkeoloji, Tarih, Kent, Kimlik. İzmir: Yakın Kitabevi.

Goody, J. (2012). Tarih Hırsızlığı. Çev. Güven, G. Ç. Türkiye İş Bankası Kültür Yayınları, İstanbul.

Güneş, A. M. (2012). Uluslararası Çevre Hukuku Üzerine Bir İnceleme. İstanbul Üniversitesi Hukuk Fakültesi Mecmuas1, 70(1): 83-114.

Güven, E. (2011). Yavaş, Güzeldir: “Yavaş Yemek'ten “Yavaş, Medya'ya Hızlı Tüketime Dair Bir Çözüm Önerisi, Selçuk İletişim Dergisi, 7(1): 113-121.

Honore, C. (2008). Yavaş: Hız Çılgınlığına Başkaldıran Yavaşlık Hareketi.Çev. Gür, E. Alfa Yayınları, İstanbul.

Jung, T., Ineson, E. ve Miller, A. (2014). The Slow Food Movement and Sustainable Tourism Development: A Case Study of Mold, Wales, International Journal of Culture, Tourism and Hospitality Research, 8(4): 432-445.

Kazcynski, T. J. (1996). Sanayi Toplumu ve Geleceği. Çev. Kaos Yayınları. Kaos Yayınları, İstanbul.

Kınacı, B. Pehlivan A. N. ve Seyhan, G. (2011). Turizm ve Çevre (Çevre Koruma). Ankara: Pegem Akademi.

Kocabaş, M. (2020). Slow Food Hareketi'ne Yönelik Etnografik Bir Araştırma: Germiyan Köyü Örneği (Yayımlanmamıs, yüksek lisans tezi). Van Yüzüncü Yıl Üniversitesi, Van.

Kurt, S. (2016). Intangible Cultural Heritage and Tourism: Germiyan Village Sample. Sözel Bildiri, Proceedings of III. International Cesme-Chios History, Culture and Tourism Symposium, Çeşme.

Kuter, N. ve Ünal, H. E. (2009). Sürdürülebilirlik Kapsamında Eko turizmin Çevresel, Ekonomik ve SosyoKültürel Etkileri, Kastamonu Üniversitesi Orman Fakültesi Dergisi, 9 (2): 146-156.

Meriç, H. G. (2016). Slow Food and Food Tourism: Foça Earth Market Case Study (Yayımlanmamıs, yuiksek lisans tezi). İzmir Kâtip Çelebi Üniversitesi, İzmir.

Nosi, C. ve Zanni, L. (2004). Moving from "Typical Products" to "Food-Related Services", British Food Journal, 106 (10/11): 779-792.

Önen, E. (1987). Germiyan Köylüleri ile Bu Köyden İzmir'e Göçenlerin Yaşama Biçimlerinin Aile Boyutunda Karşılaştııılması (Yayımlanmamıs, yüksek lisans tezi). Ege Üniversitesi, İzmir.

Önen, E. (2017). Türk ve Rumların Yarımada'da Birlikte Yaşadıkları Dönemin Kültürel İzleri: Germiyan Köyünden Örnekler, Sosyoloji Dergisi, 35: 1-19.

Özer, N. (2019). Slow Food'a İlişkin Turist Motivasyonlarının Tekrar Ziyaret Etme Niyetine Etkisi: Germiyan Köyü Örneği (Yayımlanmamış, yüksek lisans tezi). Gaziantep Üniversitesi, Gaziantep.

Özgürel, G. ve Avcıkurt, C. (2018). Yavaş Yemek (Slow Food) Hareketinin Yerli Turistler (Akademisyenler) Tarafından Algılanışı. Journal of Tourism and Gastronomy Studies, 6(4): 568-587.

Özkan, E., Curkan, S. C., ve Nisari, A. (2016, Kasım). An Investigation of the Impacts of Local Festivals on Local Residents' Satisfaction: From Germiyan Festival to The Slow Food Movement. Sözel Bildiri, Proceedings of III. International Cesme-Chios History, Culture and Tourism Symposium, Çeşme.

Pallemaerts, M. (1997). Stockholm'den Rio'ya Uluslararası Çevre Hukuku: Geleceğe Doğru Geri Adım M1?. Ankara Üniversitesi SBF Dergisi, 52(1): 613-632.

Petrini, C. ve Padovani, G. (2012). Slow Food Devrimi. Çev. Ekiz, C, Sinek Sekiz Yayınevi, İstanbul.

Seggie, F. N. ve Bayyurt, Y. (2017). Nitel Araştırma: Yöntem, Teknik, Analiz ve Yaklaşımları. Ankara: Anı Yayıncilık.

Sepúlveda, L. ve Petrini, C. (2018). Mutluluğa Dair Bir Düşünce. Çev. Gezgin, Ş. Can Yayınları, İstanbul. 
Demir, B. (2021). Sürdürülebilir Turizm Hareketi Olarak Slow Food: Germiyan Örneği. GSI Journals Serie A: Advancements in Tourism, Recreation and Sports Sciences (ATRSS), 4 (2): 1-16

Sipahi, E. B. (2010). Küresel Çevre Sorunlarına Kolektif Çözüm Arayışları ve Yönetişim. Selçuk Üniversitesi Sosyal Bilimler Enstitüsü Dergisi, 24: 331-344.

Slow Food International. (2019). https://www.slowfood.com adresinden elde edilmiştir.

Stabler, J. M. ve Goodall, B. (1997). Environmental Awareness, Action and Performance in the Guernsey Hospitality Sector. Tourism Management, 18 (1): 19-33.

Standage, T. (2017). İnsanlığın Yeme Tarihi. Çev. Çakır, G. Maya Kitap, İstanbul.

Stavrides, S. (2016). Kentsel Heterotopya: Özgürleşme Mekânı Olarak Eşikler Kentine Doğru. Çev. Karatay, A. Sel Yayıncılık, İstanbul.

Swarbrooke, J. (1999). Sustainable Tourism Management. London: CABI Publishing.

United Nations. (1987). Report of The World Commission on Environment and Development, Our Common Future.

United Nations Environment Programme (UNEP). (2009). Sustainable Coastal Tourism.(08.03.2019): http://www.unep.fr/shared/publications/pdf/dtix1091xpa-sustainablecoastaltourismplanning.pdf

Varlık, M. Ç. (1996). Germiyanoğluları.(20.03.2019): https://islamansiklopedisi.org.tr/germiyanogullari.

Yazar, Ö. (2019).Gökçeada'nın Gastronomi Rotalarında Slow Food ve Gastronomi Turizmi (Yayımlanmamıs, yüksek lisans tezi). İstanbul Okan Üniversitesi, İstanbul.

Yeşiltuna, C, D. (2016). Küreselleşme ve Kırsal Dönüşüm: Komsu Mahalleden “Butik Siteye Sandalye Marketten "Slow Food"a. Ankara: Nobel Akademik Yayıncılık.

Yıldırım, A. ve Şimşek, H. (2018). Sosyal Bilimlerde Nitel Araştırma Yöntemleri. Ankara: Seçkin Yayıncılık.

Yurtseven, H. R. Kaya, O., ve Harman, S. (2010). Yavaş, Hareketi. Ankara: Detay Yayıncılık. 